Volume: 12 Issue: 1 Year: 2015

\title{
Dimensional comparatives of organizational citizenship and emotional labor: A study on accommodation companies
}

\author{
Ülker Çolakoğlu ${ }^{1}$ \\ Gülseren Yurcu ${ }^{2}$ \\ Hakan Atay ${ }^{3}$ \\ Akan Yanık ${ }^{4}$
}

\begin{abstract}
This study determines the effects of organizational citizenship behavior on the emotional labor by depending on the theory that exhibiting organizational citizenship behavior might reduce the negation emotional labor expenditure might create. As a result, a significant positive correlation between organizational citizenship behavior and emotional labor has been found. To put it more explicitly; the employees exhibiting organizational citizenship behavior gain a stronger position against the negative effects of emotional labor expenditures. Positive correlation occurs, in the superficial entreating phase of emotional labor. While employees are harmonizing their real feelings which appear in the phase of deep entreating according to the norms of organization and the duty, organizational citizenship behavior has a positive impact. In other words; it can be said that organizational citizenship behavior affects the function of emotional regulation in a positive way. At this point; it can be possible to regulate and manage the deep negative effects of emotional labor on the employees by means of organizational motivators.
\end{abstract}

Keywords: Tourism, Organizational citizenship behavior, Emotional labor.

\section{Introduction}

Human resource, the biggest factor in the social, economic and political development of the community (Acquaah, 2004:118), should, with effectuality, be enthusiastic about organizational contribution under ever-changing circumstances, independent from formal job-descriptions and beyond the necessity of duty (Wagner and Rush, 2000; Somech and Drach-Zahavy, 2004). Several studies have been performed on raising organizational effectiveness and contribution,

\footnotetext{
${ }^{1}$ Asst. Prof., Adnan Menderes University, Faculty of Tourism, Aydin, ucolakoglu@adu.edu.tr

2 Ph.D.., Adnan Menderes University, Sultanhisar Vocational High School, Aydin, gcetin@adu.edu.tr

${ }^{3}$ Asst. Prof., Adnan Menderes University, Faculty of Tourism, Aydin, hakanatay@gmail.com

${ }^{4}$ Ph.D., Adnan Menderes University, Vocational High School, Aydin, akanyanik@gmail.com
} 
Çolakoğlu, Ü., Yurcu, G., Atay, H., \& Yanık, A. (2015). Dimensional comparatives of organizational citizenship and emotional labor: A study on accommodation companies. International Journal of Human Sciences, 12(1), 933950. doi: $10.14687 /$ ijhs.v12i1.3086

emphasizing the concepts like organizational commitment, job satisfaction, motivation and organizational justice. One of the issues on organizational effectiveness in the field of organizational behavior and human resource management which has especially been highlighted in the recent years is organizational citizenship behavior (Organ, 1997; Podsakoff and MacKenzie, 1997; Turnipseed and Murkison, 2000; Blakely et al, 2003; Finkelstein and Penner, 2004; Lievens and Anseel, 2004; Vey and Campbell, 2004). Today, as organizations have expectations from their employees beyond the formal job responsibilities, organizational citizenship behavior is of main importance. These days, particularly in the service sector in which face to face communication is intense, the importance of human resource approach which emphasizes on initiative, creativity, empowerment, autonomy and strengthening instead of personnel management mentality depending on obedience and discipline is increasing. In this process, organizational citizenship behavior mentality aims to create a working system that tries to maximize all of the human resource behaviors in favor of the institution.

Organizational citizenship behavior is a human resource behavior which is more needed especially in the labor-intensive sectors. For instance, in tourism, which is labor-intensive, the behavior models of human resource are more important than the other sector. Customer satisfaction depends on the quality of informal presentation in touristic businesses where the customer purchasing the service and the human resource providing it are in an intense informal communication. Organization, in a system with an extremely rapid global change, tries to serve among the possibilities exceeding the intended case analysis power. Within the extreme possibilities employees voluntarily solve those possibilities with his natural intelligence beyond the formal job descriptions and by maximizing personal and organizational effectiveness factors. Organizational citizenship behavior also includes an emotional process as it is the complement of volunteer efforts of employees in the organization. This study, which is examining organizational citizenship behavior as an emotional process, is going to use the concept of emotional labor and the factors of this concept while it is searching emotional processes of the behavior quantitatively.

Emotional labor concept concerns all of the employees predominantly in the service sector and in all sectors where there is face to face communication. Hochschild (1983) introduced this concept to literature via his study on the topic of 'effects of emotional nature of hostesses working on airplanes on their jobs'. The concept briefly expresses obeying various certain rules while exhibiting emotions. Beside this, other studies in which different occupational groups like crew, teachers, nurses, holiday guides and tourist guides involved are available. (Murphy, 1998; 
Çolakoğlu, Ü., Yurcu, G., Atay, H., \& Yanık, A. (2015). Dimensional comparatives of organizational citizenship and emotional labor: A study on accommodation companies. International Journal of Human Sciences, 12(1), 933950. doi: $10.14687 /$ ijhs.v12i1.3086

Shuler and Syper, 2000; Tracy, 2000; Price, 2001; Callaghan and Thompson, 2002; Levig and Dollard, 2003; Constanti and Gibbs, 2005; Man and Öz, 2007; Truc, Marie and Marry, 2008; Wong and Wang, 2009; Gray and Smith, 2009; Hülsheger, Lang and Maier, 2010). The concept of emotional labor is also being discussed as a philosophical issue. In these studies, capitalism is seen as an economy mentality which commodities human and is criticized by interpreting the presentation of human emotions in accordance with organization process as the reflection of this commoditization. Proper measurement of emotional labor can not only enable organizations set their employees' emotional labor degrees but also determine emotional labor effort that customers want employees to exhibit (Chu and Murrmann, 2006).

In the light of the studies, it is seen that both concepts put emphasis on the behavioral side of labor force in service businesses. As organizational citizenship behavior is conceptualized as the employee's volunteer exhibition of over-role behavior; emotional labor is the employee's necessary management of his emotions against the sudden situations appears in the workplace according to social norms of work environment. At first glance these two concepts can be regarded as antipodes. While emotional labor behavior is including a certain undesired effort; OCB has an opposite nature and is based on the basis of voluntariness. Hence, detecting which point these two concepts affect each other positively or negatively might light the way to the solution of some issues in managerial sense. The aim of this study is to determine the reciprocal influence between emotional labor behavior and organizational citizenship behavior.

\section{Literature review}

\subsection{Organizational citizenship behavior}

Organizational citizenship behavior could be defined as individual's voluntary effort beyond the job description and the standards specified for him in the workplace and exhibiting over-role behaviors (Organ, 1988:4) and it can also be defined as an employee's exhibit of over-role behaviors (McDonald, 1993; Schnake and Dumler, 2003; Feather and Rauter, 2004) or going beyond the call of duty by transcending the necessity that the organization assigned him through formal methods (Greenberg and Baron, 2000:212). Organizational citizenship behavior is also explained as behavior which increases employees' performances in social and physiological environment which they execute their duties in the organization (Organ, 1997:86). The approach that Katz suggested in 1964 as "a management mentality depending on fulfilling only the written duties will generate an immensely fragile social structure" (Moideenkutty 2000:2) has brought the 
Çolakoğlu, Ü., Yurcu, G., Atay, H., \& Yanık, A. (2015). Dimensional comparatives of organizational citizenship and emotional labor: A study on accommodation companies. International Journal of Human Sciences, 12(1), 933950. doi: $10.14687 /$ ijhs.v12i1.3086

concept of "extra role behavior" to life. During the next 25 years or in other words until Organ, these approaches of Katz had been the accelerators of studies rather related to employees' personal skills, experience, intellectual power and knowledge. Organ, who is generally accepted as the mastermind of this concept, offered a crucial insight into the field of management and organization via his hypothesis he developed in 1977 which is expressed as "Satisfaction-CausesPerformance". After Organ's studies and after OCB took part in literature, a significant interest has aroused in the literature in studying the employees' discretionary behaviors and as a consequence of those behaviors, studying the physiological and social environment of the organizations (Olson, 2004:2).

Organizational citizenship behavior is not observed at every business and/or in every employee. In the researches related to the issue, it is proved that the determiners providing these kind of behaviors are the employees' personal features, organizational features, leader behaviors and the features of the job (Podsakoff et al., 1997; Moorman, 1991; Moorman et al., 1998). In accordance with these determiners, since the OCB is beyond the formal role necessities, revealing the behaviors is not possible through punishment (Smith at al, 1983: 654), nor are they directly linked to the reward system (Moorman and Blakely, 1995:127). Embracement and behaviors displayed voluntarily underlie in the core of organizational citizenship behavior (Deluga, 1995:1 2). Motowidlo and Borman (1997) state that organizational citizenship behaviors contribute to organizational effectiveness in terms of forming organizational and social environment by supporting employees' activities of duty. The concept focuses on the personal behaviors based on voluntariness that assist the organizational objective to be achieved by contributing social and psychological environment of the organization (Lievens and Anseel, 2004).

According to Organ's definition, an individuall behavior must have two qualities in order to be accepted as an organizational citizenship behavior. First; behavior is supposed to hold qualification which boosts efficiency and increases the productivity of the organization and gains favor toward the objectives of the organization. Second; the necessity that behavior must not be proposed to be rewarded in job description, in employment agreement or in any official document of the organization, rather it must be chosen by individual at his sole discretion. Therefore it is the behavior based on personal choice and does not require any penalty when it is not implemented (Smith, et al., 1983: 653; Williams and Anderson, 1991). However, Organ, who states that changes in work and social life also forces the meaning of organizational citizenship behavior to change, has started to interpret the relationship between organizational behavior and rewarding differently, in time. Beside the fact that the inadequacy in exhibiting organizational 
Çolakoğlu, Ü., Yurcu, G., Atay, H., \& Yanık, A. (2015). Dimensional comparatives of organizational citizenship and emotional labor: A study on accommodation companies. International Journal of Human Sciences, 12(1), 933950. doi: $10.14687 /$ ijhs.v12i1.3086

citizenship behavior does not necessitate any sanction, such behaviors might be rewarded, approved and appreciated by the organization in time because the employees exhibiting organizational citizenship behaviors might get a rise or promotion by leaving a positive impression on the organizations' administrators and other employees.

Organ (1988) has examined organizational citizenship behavior in 5 dimensions. Although there has been different dimensionings of organizational citizenship behavior by other researchers (Podsakoff et al., 1997); Organ's (1988) five-staged dimensioning version referred as altruism, courtesy, conscience, chivalry and virtue of membership, has come in sight as the most commonly used dimensioning in literature (Organ and Konovsky, 1989; Moorman, 1991; Moorman et al., 1993; Vey and Campbel, 2004). In Organ's dimensioning, organizational citizenship behavior correlates with the variables like organizational participation, peer pressure, supervisor's support, autonomy, task orientation, clarity of duty, innovation and physical comfort. Daily effort spent on the duty and personal productivity also have a positive relation with organizational citizenship behavior (Turnipseed and Murkison, 2000). Likewise, Finkelstein and Penner (2004) investigated the relationship between organizational citizenship behavior and the incentive factors of it and concluded that in determining organizational citizenship behavior, incentives related to the desire of assisting co-workers and/or organization are more effective than the ones related to the desire of impressing top executives. In another study (Vey and Campbell, 2004); within a list involving organizational citizenship behavior and in-role behavior, most of the participants (\%85), qualified 17 out of 30 organizational citizenship behavior as inrole behavior. This indication can be interpreted as that many behaviors, which are actually presumed as organizational citizenship behavior are, by the employees, appraised just as the necessity of the usual duty.

It is stated that organizational citizenship behavior basically affects organizational environment at three points. First, the employees' citizenship behaviors increase the tendency of inter-organizational assistance; second, it improves the employees' sense of responsibility; and third, it increases the personal performance measures of the employees by developing their positive attitudes. Concordantly; it is also stated that there can be such consequences as that organizational citizenship behaviors assist increasing the productivity and performance of the employee and the organization, interpersonal harmony, smooth orientation to organizational environment variables and improving productivity in using and sharing sources (Schnake and Dumler, 2003:285). 
Çolakoğlu, Ü., Yurcu, G., Atay, H., \& Yanık, A. (2015). Dimensional comparatives of organizational citizenship and emotional labor: A study on accommodation companies. International Journal of Human Sciences, 12(1), 933950. doi: $10.14687 /$ ijhs.v12i1.3086

Organizational citizenship behavior is in relation with emotional labor behavior particularly in terms of smooth orientation to the variables of organizational environment. Even though the processes of developing behaviors are different, the potential relationship between the ratio of possessing organizational citizenship behavior and the tension that emotional labor behavior creates is a significant motive for the emotional labor behavior to be examined in detail.

\subsection{Emotional labor}

The concept of emotional labor was first mentioned by Arlie Hochschild in 1983. In his book called "The Managed Heart", two main approaches, organismic and interactive, take place related with defining emotions. In organismic approach, emotions come up as a sudden reflex which depends on instincts and impulses; in interactive approach, on the other hand, emotions are handled in a more social structure (Hochschild,1983). Primary components that conceptual structure of emotional labor involves are; (a) appearing through face to face or oral communication with the customers; (b) exhibiting emotions via the effect of other people's emotions, attitudes or behaviors and (c) the obligation that reflecting the emotions must follow certain rules (Hochschild, 1983; Morris and Feldman, 1997; Zapf, 2002). The rules mentioned here are the social, occupational and organizational norms that people are obliged to follow whilst exhibiting emotions (Asforth and Humprey, 1993). For instance, these sort of social norms are able to identify how emotions are needed to be reflected to a customer in a service presentation. When viewed from this aspect; the fact of exhibiting emotions is more specific and situational than general and social norms (Wong and Wang, 2009). Most of the time employees are face to face with a burden called affective disharmony as they are obliged to express emotions, which they actually do not intend, due to the pressure of norms that environment offers. Despite the fact that exhibiting counterfeit emotions is actually not a formal procedure of the duty (Hochschild, 1983; Wong and Wang, 2009), it creates an informal necessity because of the fact that the organization is also described as a social environment and it has social norms.

When the concept of emotional labor is examined, particularly in the emergence process of the behavior, we are fronted that the employee manages his emotions in two ways (Chu and Murrman, 2006; Sutton and Rafaeli, 1988; Huang and Dai, 2010). At the first stage; employee's internal emotions are created, namely as some sort of reflex, in a way that is necessary for the current situation. At the second stage, on the other hand, these emotions are reformed and exhibited to the other side in line with the obligations that social rules bring. At this very point, 
Çolakoğlu, Ü., Yurcu, G., Atay, H., \& Yanık, A. (2015). Dimensional comparatives of organizational citizenship and emotional labor: A study on accommodation companies. International Journal of Human Sciences, 12(1), 933950. doi: $10.14687 /$ ijhs.v12i1.3086

two types of behavioral pattern come up called 'deep acting' and 'surface acting' (Hochschild, 1983; Koskina and Keithley, 2010; Hwa, Thurasamy and Wafa, 2010).

Ashford and Humprey (1993) has added a third dimension as 'intimate acting' into the pattern that Hochschild handled in two dimension called deep acting and surface acting by differently interpreting the concept of emotional labor from his definition. From the authors' point of view, some emotions which are expected to be conveyed to the sharer might be born willingly and without any obligation by the employee. For example, through the communication he develops with children and through his daily shares, a kindergarden employee may understand the children, show them affection, and empathize with them without any obligation (Ashford and Humprey, 1993). In the light of these definitions, Grandley (2000) indentified emotional labor as arranging both emotions and behaviors in such a manner that they serve for the objectives of organization. In his studies the author has suggested that exhibition of emotional labor may make positive contributions to organizations owing to the fact that it gives employees the opportunity of emotion regulation.

Emotion regulation is individual's control of his emotions and generating appropriate responses for situations by achieving his emotional balance when he meets the stimulus (Grandey, 2000). However, the vital point here is to what extent the individual pretends. The fact that the individual pretends emotions that he is obliged to exhibit but actually does not intend to, may cause some negative consequences (Abraham, 1998; Cordes and Doherty, 1993; Erickson and Wharton, 1997). At this point, during the recruitment process, organizations can pay attention to select candidates who are capable of managing their emotions properly or at least they can ensure employee to have an early awareness by estimating how much emotional labor the duty requires.

\subsection{Measure of correlation between organizational citizenship behavior and emotional labor}

When literature is reviewed, it can be realized that there are several different aspects of organizational citizenship behavior and emotional labor behavior, and some direct convergence points between them. For this reason; organizational citizenship and emotional labor concepts could not be addressed together in literature. However, in this study, they are examined assuming that there will be an indirect positive relation between the factors of two concepts whose differences are directly presented. 
Çolakoğlu, Ü., Yurcu, G., Atay, H., \& Yanık, A. (2015). Dimensional comparatives of organizational citizenship and emotional labor: A study on accommodation companies. International Journal of Human Sciences, 12(1), 933950. doi: $10.14687 /$ ijhs.v12i1.3086

To mention briefly the direct convergence points encountered in literature; while Asforth and Humprey (1993) define emotional labor as the social, occupational and organizational norms which the employee is obliged to obey, organizational citizenship behavior is individual's voluntary effort beyond the job description and the standards specified for him in the workplace and exhibiting over-role behaviors (Organ, 1988: 4). Besides; whereas it is explicitly remarked in the written and unwritten sources of the organization, educational seminars and case analysis that emotional labor behavior is a norm organizational citizenship behavior is defined as individual's voluntary effort beyond the job description and the standards specified for him in the workplace (Organ, 1988:4). The other direct difference is about the punishment and reward systems. Since emotional labor behavior is a necessary emotion regulation against the certain norms, it is regulated via a certain punishment and reward system; yet, since the organizational citizenship behavior is beyond the formal role necessities, neither it is possible to reveal organizational citizenship behaviors through punishment (Smith et al., 1983:654) nor there is a direct correlation between the behavior and the reward systems (Moorman and Blakely, 1995:127).

When the concepts of organizational citizenship behavior and emotional labor is analyzed from a correlation point of view beyond the direct differences; every employee in the organization may not express organizational citizenship behavior while exhibiting emotional labor up to a certain degree. However, when Ashford and Humprey's (1993) intimate acting dimension is taken into consideration, every organizational citizenship behavior involves emotional regulation just as emotional labor behavior does. Both concepts actually refer to a definite emotional labor and emerge informally. The starting point of the correlation intended to be clarified in this study is the idea that high organizational behavior level will reduce the negative effects that emotional labor waste brings. In accordance with this idea, employees in tourism industry are not be able to avoid negative effects of emotion regulation behavior which exists in the nature of service encounter. Nonetheless, the possibility that the ones exhibiting organizational citizenship behavior may be exposed less to these negative effects stands as a point to be examined. In this regard, the hypotheses of the study are as follows:

$H_{1}$ : There is a positive correlation between the employees' organizational citizenship behavior and emotional labor behavior.

As a result of the literature review on organizational citizenship behavior and emotional labor it is thought that these two behaviors have a significant positive correlation on some particular factors as they are both psychologically emotional regulation behaviors. 
Çolakoğlu, Ü., Yurcu, G., Atay, H., \& Yanık, A. (2015). Dimensional comparatives of organizational citizenship and emotional labor: A study on accommodation companies. International Journal of Human Sciences, 12(1), 933950. doi: $10.14687 /$ ijhs.v12i1.3086

$H_{2}:$ The dimensions of organizational citizenship behavior positively affect the dimensions of emotional labor.

As long as emotional regulation in the behavior increases, it slips towards a line from voluntariness to obligation. For this reason, in the behaviors involving intense emotion regulation, mostly the relation searched is of emotional labor behavior but not of organizational citizenship behavior. Looking into factors of emotional labor, the possibility of emotional regulation gradually increases in the sequence of factors surface acting, repression and deep acting. As the details of psychologically natural process can be examined over the surface acting; in repression and deep acting, individual intensively shows a tendency to regulate emotions against the social and organizational norm pressure of the environment. Particularly because repression factor contains a heavy psychological emotion regulation, establishing a statistically significant relation with organizational citizenship behavior is not expected.

\section{Methodology}

The data necessary for the study has been gathered from 36 five-star accommodation businesses which hold tourism operation lenience form Ministry of Tourism and Culture, operating in Antalya, Afyon, İstanbul, Aydın, Ankara in the period of the year 2012 FebruaryApril. Since reaching and conducting a questionnaire to all of the main mass consisting population is practically impossible, sampling method is applied. 497 employees in 36 accommodation businesses in cities mentioned above constitute the sample of the study. Employees to whom questionnaire conducted are selected via random sampling. Totally 600 questionnaires are distributed through pollsters and necessary explanations are made directly to the participants. 503 questionnaires out of 600 distributed to employees are received back and a feedback rate of is achieved. 497 of the received questionnaires are regarded as available and analyzed in order to examine the hypothesis.

Questionnaire consists of three parts. The first section includes demographic variances, the second section includes emotional labor scale and the third section includes organizational citizenship behavior scale. Emotional labor behaviors are regarded as independent variance and organizational citizenship behaviors are regarded as dependent variance.

Emotional labor behavior scale is developed by Grandey (2000) in order to measure emotional labor effort in environment of the organization. Within this scope 19 items involving emotional labor behavior oriented to its three dimensions (superficial behavior, suppression, deep behavior) 
Çolakoğlu, Ü., Yurcu, G., Atay, H., \& Yanık, A. (2015). Dimensional comparatives of organizational citizenship and emotional labor: A study on accommodation companies. International Journal of Human Sciences, 12(1), 933950. doi: $10.14687 /$ ijhs.v12i1.3086

are included. Each statement is measured by scales prepared in Likert type ranging as $1=$ Never and $5=$ Almost always.

Organizational citizenship behavior scale is developed by Ehrhart (2001), Evans (2001), Love (2001), Liao (2002) and Reis (2002) in order to measure organizational citizenship behaviors of the employees. Within this scope 20 items involving organizational citizenship behavior oriented to its five dimensions (altruism, conscience, courtesy, chivalry and civilian virtue) are included. Each statement is measured by scales prepared in Likert type ranging as $1=$ Never and $5=$ Almost always.

As demographic variables; 10 questions are asked to participants like their ages, genders, levels of education, marital status and staff status and participant are expected to mark the appropriate ones.

Data gathered by means of question forms is analyzed via SPSS 16 statistical data analysis package software. Data regarding demographical variances is evaluated by using frequency and percent values. Correlation and regression analysis are applied to measure the relation between variances and multiple regression analysis is implemented in order to determine whether organizational citizenship behavior has an effect on emotional labor behavior or not. Once again multiple regression analysis is applied to be able to detect the effects of organizational citizenship behavior dimensions on emotional labor behavior.

\section{Results}

Factor analysis is implemented in order to test the construct validity of emotional labor and organizational citizenship behavior scales. After factor analysis and varimax rotation is accomplished, eigenvalue of emotional labor scale is determined as three dimensions bigger than one, and these three dimensions presents $60,095 \%$ of total variance. Organizational citizenship behavior scale is identified as four dimensions according to eigenvalues and these four dimensions presents $67,628 \%$ of total variance. Kaiser-Meyer-Olkin (KMO) test is applied so as to examine the sufficiency of sample size and Barlett Sphericity test is implemented to be able to identify whether variances has normal distribution or not. KMO value of Organizational citizenship behavior scale is 0,908 while $\mathrm{KMO}$ of emotional labor scale is 0,860 . The results of Barlett Sphericity test are significant. In the validity and reliability analysis of scale the Cronbach Alpha coefficient is 0,92 . In the given transformed component matrix in the table below, the fact that the variances used in this study is gathered under which factors is displayed. 
Çolakoğlu, Ü., Yurcu, G., Atay, H., \& Yanık, A. (2015). Dimensional comparatives of organizational citizenship and emotional labor: A study on accommodation companies. International Journal of Human Sciences, 12(1), 933950. doi: $\underline{10.14687 / \text { ijhs.v12i1.3086 }}$

Table 1. Factor analysis and scale reliabilities of dependent and independent variables

\begin{tabular}{|c|c|c|c|c|c|}
\hline Variables & Items & $\begin{array}{l}\text { Factor } \\
\text { loading }\end{array}$ & $\begin{array}{l}\text { Reliability } \\
\text { coefficient }\end{array}$ & $\begin{array}{c}\text { Factor } \\
\text { variance }\end{array}$ & Eigenvalue \\
\hline \multirow{6}{*}{$\underbrace{\infty}_{\substack{0 \\
\hdashline}}$} & $\begin{array}{l}\text { - I talk to even my furious customers trying to look } \\
\text { at the events from their point of view. }\end{array}$ & 684 & \multirow{6}{*}{85} & \multirow{6}{*}{27,881} & \multirow{6}{*}{4,850} \\
\hline & $\begin{array}{l}\text {-I put a sincere effort in order to be the 'person' } \\
\text { that my job asks me to. }\end{array}$ & ,759 & & & \\
\hline & $\begin{array}{l}\text {-Even if I feel upset or angry, I behave in a friendly } \\
\text { way and smile. }\end{array}$ & ,762 & & & \\
\hline & $\begin{array}{l}\text { - Even if the feeling that I should reflect during the } \\
\text { interaction with the customer does not fit my } \\
\text { mood, I pretend to reflect such an emotion. }\end{array}$ & ,663 & & & \\
\hline & $\begin{array}{l}\text { - During the interaction with the customer, even if } \\
\text { it is abhorrent to my feelings, I try to feel the } \\
\text { emotion that I should reflect according to my job. }\end{array}$ & ,783 & & & \\
\hline & $\begin{array}{l}\text {-I put an effort in order not to make the customers } \\
\text { feel the emotions that I feel inside. }\end{array}$ & ,719 & & & \\
\hline \multirow{4}{*}{ 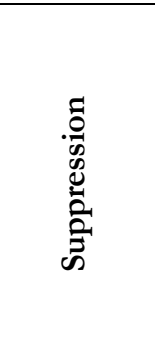 } & -I make an effort to not show my real feelings. & 808 & \multirow{4}{*}{,78 } & \multirow{4}{*}{19,615} & \multirow{4}{*}{1,753} \\
\hline & -I pretend to feel emotions that I don't. & ,791 & & & \\
\hline & $\begin{array}{l}\text {-I make an effort to feel the emotions that I should } \\
\text { display. }\end{array}$ & 690 & & & \\
\hline & $\begin{array}{l}\text {-I make an effort to hide my real feelings at the } \\
\text { time of the interaction. }\end{array}$ & ,690 & & & \\
\hline \multirow{3}{*}{ 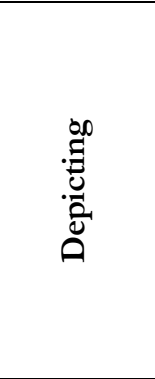 } & $\begin{array}{l}\text { - I act to be able to reflect the feelings that my } \\
\text { organization asks me to show during the interaction } \\
\text { with the customer. }\end{array}$ & 607 & \multirow{3}{*}{, 55} & \multirow{3}{*}{12,599} & \multirow{3}{*}{1,209} \\
\hline & $\begin{array}{l}\text { - I act during the interaction with the customer in } \\
\text { order not to reveal that I'm troubled or furious. }\end{array}$ &, 546 & & & \\
\hline & $\begin{array}{l}\text { - Even if I'm angry with the customer, I keep on } \\
\text { behaving him/her well, but I say bad words silently }\end{array}$ & 816 & & & \\
\hline \multicolumn{6}{|c|}{ KMO:0,860p:,000 (Barlett's test) Total variance:60,095 } \\
\hline \multirow{6}{*}{ 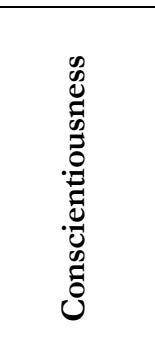 } & -I come to work on time. & ,759 & \multirow{6}{*}{89} & \multirow{6}{*}{23,615} & \multirow{6}{*}{6,896} \\
\hline & -I care about completing the given tasks on time. & ,786 & & & \\
\hline & -I obey the company rules. & ,749 & & & \\
\hline & -I avoid taking actions that hurt my colleagues. & ,745 & & & \\
\hline & -I try to avoid creating problems for my colleagues. & 697 & & & \\
\hline & -I avoid hurting my colleagues' rights. & 677 & & & \\
\hline \multirow{3}{*}{ 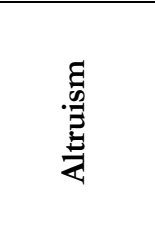 } & -I help new colleagues adjust to work environment. & ,791 & \multirow{3}{*}{87} & \multirow{3}{*}{18,740} & \multirow{3}{*}{1,769} \\
\hline & $\begin{array}{l}\text {-I help my colleagues solve their work-oriented } \\
\text { problems. }\end{array}$ & ,781 & & & \\
\hline & -I do my colleagues' tasks when they need. & 800 & & & \\
\hline
\end{tabular}


Çolakoğlu, Ü., Yurcu, G., Atay, H., \& Yanık, A. (2015). Dimensional comparatives of organizational citizenship and emotional labor: A study on accommodation companies. International Journal of Human Sciences, 12(1), 933950. doi: $10.14687 /$ ijhs.v12i1.3086

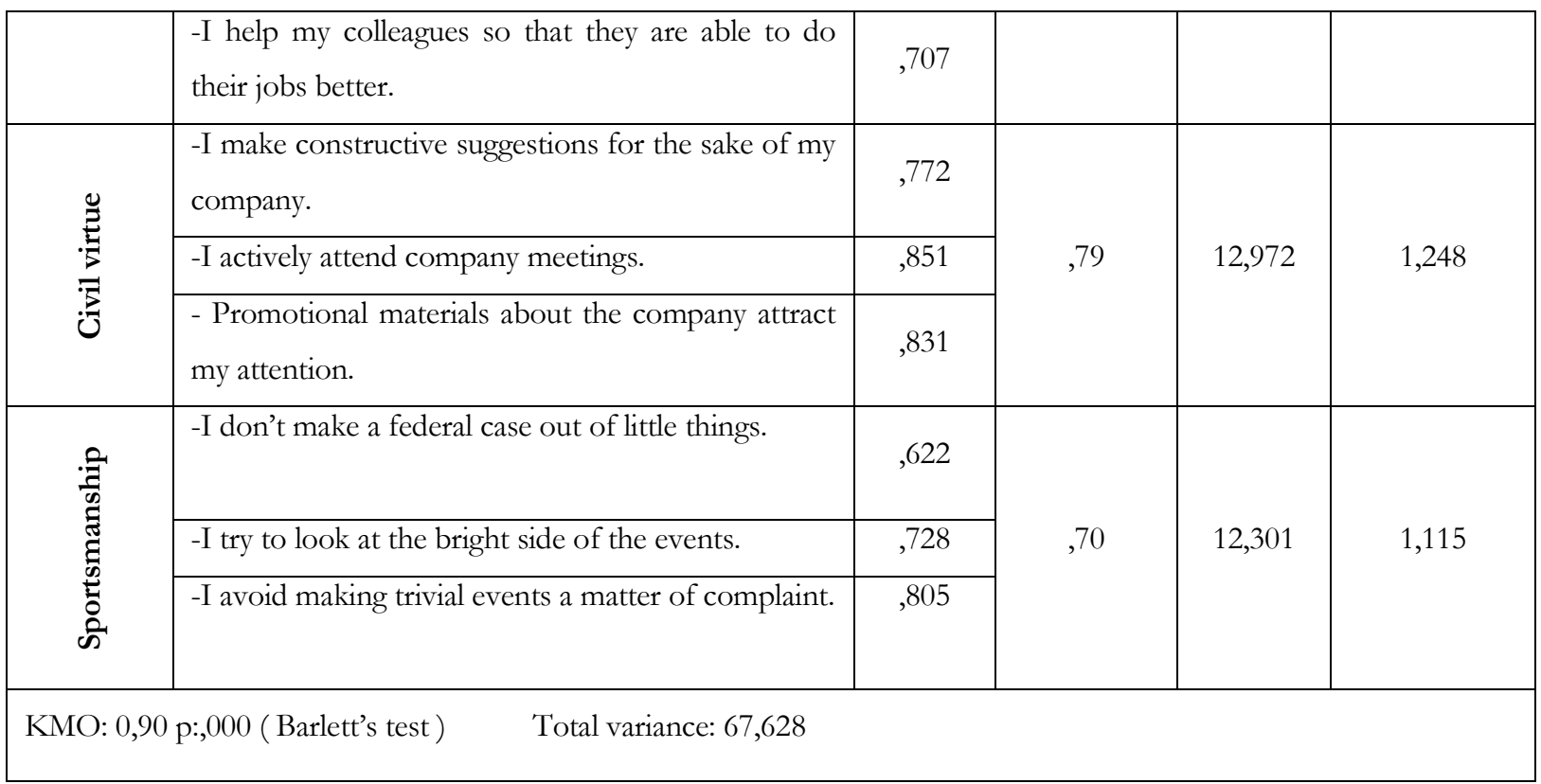

Since in the factor analysis values of 0,50 and above in the matrix were taken into account, questions numbered “ $5,6,7,9,17,18$ ” out of 19 variances consisting emotional labor scale and questions numbered " $5,16,17$ " out of 20 variances consisting organizational citizenship behavior scale are excluded. These variances are the overweighing ones and so the ones determining the factor. As Cronbach Alpha value concerning factors should be positive and over 60\% (Nakip, 2003), received value indicates that the scales are notably reliable.

The data of the employees participated in the research is evaluated by using frequency and percent values. 305 of the participants $(61,5 \%)$ are male and $164(32,5 \%)$ are female, average of age is between the range of $27-35(\% 39,6)$, in terms of educational status 204 of the participants $(41,8 \%)$ are graduated from high school, $12(25 \%)$ of them are post graduate and $(0,2 \%)$ are phd degree. About marital status, 226 of the participants $(\% 46,3)$ are married, $262(53,7 \%)$ are single. $84 \%$ of the participants enjoy their job and $89 \%$ consider stay in the sector. In terms of staff status $76,3 \%$ of the participants are permanent and the number of employees employed in the sector for less than 10 years corresponds to $76,3 \%$, the number of the ones employed in the same business between 1 and 5 years corresponds to \% 75,5.

In table 2, organizational citizenship behavior and its factors and emotional labor and its factors are compared via factor analysis. Positive correlation $(r=, 554 * *)$ is confirmed between organizational citizenship behavior and emotional labor. Additionally the positive correlation is confirmed between emotional labor and organizational citizenship behavior dimensions known as altruism $\left(\mathrm{r}=, 342^{* *}\right)$, conscience $\left(\mathrm{r}=, 318^{* *}\right)$, courtesy $\left(\mathrm{r}=, 169^{* *}\right)$, and chivalry $\left(\mathrm{r}=, 265^{* *}\right)$. While a high positive correlation is observed between organizational citizenship behavior and 
Çolakoğlu, Ü., Yurcu, G., Atay, H., \& Yanık, A. (2015). Dimensional comparatives of organizational citizenship and emotional labor: A study on accommodation companies. International Journal of Human Sciences, 12(1), 933950. doi: $10.14687 /$ ijhs.v12i1.3086

superficial behavior $\left(\mathrm{r}=, 678^{* *}\right)$ which is an emotional labor behavior factor, a slight correlation is observed between suppression $\left(\mathrm{r}=, 121^{*}\right)$ and deep behavior $(\mathrm{r}=, 071)$.

Table 2. Correlation matrix

\begin{tabular}{|c|c|c|c|c|c|c|c|c|c|c|c|}
\hline Scale & $\mathbf{N}$ & Mean & St. & & 1 & 2 & 3 & 4 & 5 & 6 & 7 \\
\hline Emotional Labor & 493 & 4,173 & ,9951 & & & & & & & & \\
\hline 1 Acting & 492 & 4,676 & 1,1261 & & 1 & & & & & & \\
\hline \multirow[t]{2}{*}{2 Suppression } & 492 & 3,690 & 1,3845 & & ,002 & 1 & & & & & \\
\hline & & & & & ,977 & & & & & & \\
\hline \multirow[t]{2}{*}{3 Deep Acting } & 490 & 3,832 & 1,3439 & & ,038 & ,003 & 1 & & & & \\
\hline & & & & & , 475 & ,948 & & & & & \\
\hline \multirow[t]{2}{*}{ 4Conscientiousness } & 475 & 5,179 & 1,0185 & &, $439^{* *}$ & ,076 &,- 013 & 1 & & & \\
\hline & & & & & ,000 & ,147 & 803 & & & & \\
\hline \multirow[t]{2}{*}{5 Altruism } & 475 & 4,837 & 1,1822 & ,554 &, $381^{* *}$ & ,080 &,- 049 & ,001 & 1 & & \\
\hline & & & & &, 000 & ,131 & ,357 & ,983 & & & \\
\hline \multirow[t]{2}{*}{6 Civil Virtue } & 472 & 4,514 & 1,3706 & &, $114^{*}$ & ,006 &, $221^{* *}$ &,- 036 & 017 & 1 & \\
\hline & & & & & ,030 & ,906 &, 000 & ,499 & ,754 & & \\
\hline \multirow[t]{2}{*}{7 Sportsmanship } & 473 & 4,873 & 1,1574 & &, $297^{* *}$ & ,071 & ,102 &,- 007 &,- 015 & 000 & 1 \\
\hline & & & & & ,000 & ,179 & ,052 & ,888 &, 775 & ,992 & \\
\hline 8Organizational & 476 & 4,917 & ,89760 & & & & & & & & \\
\hline Citizenship & & & & & & & & & & & \\
\hline
\end{tabular}

**. Correlation is significant at the 0.01 level (2-tailed).

*. Correlation is significant at the 0.05 level (2-tailed).

The relation between the control variances and organizational citizenship behavior and its factors and emotional labor behavior and its factors is as follows: A significant positive correlation between organizational citizenship behavior and its dimensions and control variance is observed in only age $\left(\mathrm{r}=, 100^{*}\right)$ and job experience $\left(\mathrm{r}=, 103^{*}\right)$. By the time correlation levels are examined on the factors; it is noticed that the variances of age $\left(r=, 161^{* *}\right)$ and job experience $(\mathrm{r}=, 129 * *)$ are predominantly more related to the factor 3 namely "Conscience".

To be able to identify the effect of organizational citizenship behavior on the dimensions of emotional labor, multiple regression analysis is applied. The model created clarifies 479 of emotional labor behavior $(\mathrm{F}=92,260 ; \mathrm{p}<.001)$. Therefore organizational citizenship has an acceptable explanatory power on emotional labor. According to the obtained model and ANOVA results; Hypothesis 1 stated as "There is a significant positive correlation between 
Çolakoğlu, Ü., Yurcu, G., Atay, H., \& Yanık, A. (2015). Dimensional comparatives of organizational citizenship and emotional labor: A study on accommodation companies. International Journal of Human Sciences, 12(1), 933950. doi: $10.14687 /$ ijhs.v12i1.3086

employees' organizational citizenship behavior and emotional labor behavior." is accepted. On the other hand, it can be seen that from $\beta$ values, the factor that organizational citizenship behavior is effective the most it is the "Superficial Behavior" factor which is one of the factors of emotional labor behavior $(\beta=.543, \mathrm{t}=1,233)$. Effects on the other factors are as follows; Suppression ( $\beta=.002, \mathrm{t}=.005)$ and deep behavior $\beta=-0.012, \mathrm{t}=-0.042)$. "Superficial Behavior" $(\beta=.543)$ makes the most contribution in the model. In the direction of these results obtained; hypothesis 2 is accepted which states as "In the inter-behavioral relation; organizational citizenship behavior has positive effect more on the factor of "Superficial Behavior".

Table 3. The effects of organizational citizenship dimensions on emotional labor

\begin{tabular}{lllllll}
\hline \multirow{2}{*}{$\begin{array}{l}\text { Dependent } \\
\text { Variable }\end{array}$} & Independent & \multicolumn{2}{l}{ Coefficient } & & \\
& Variable & S & S. & t & F & $\mathrm{R}^{2}$ \\
& Altruism &, 330 &, 041 & 7,996 & & \\
Emotional Labor & Conscience &, 318 &, 041 & 7,696 & 46,033 & 0,307 \\
& Courtesy &, 172 &, 041 & 4,176 & & \\
& Chivalry &, 267 &, 041 & 6,464 & & \\
\hline
\end{tabular}

46,033 $\mathrm{F}$ value in the table indicates that our model is significant as a whole in each level (Sig. $=, 000)$. Each of the variances included in the model from statistical $\mathrm{t}$ value which belongs to parameters is observed as individually significant (at \%5 level of meaningfulness). "Altruism" which has the highest $B$ value (,330) is relatively the most important independent variance. Among the factors effecting emotional labor; conscience, courtesy and chivalry levels explain the level of emotional labor at the rate of $0,307(\mathrm{R} 2=0,307)$.

\section{Conclusions}

The aim of this study is to indentify (i) the effects of organizational citizenship behavior on emotional labor and (ii) the effects of job affection on organizational behavior. The findings gathered from the study will provide crucial information to the general managers and human resource managers so that they will be able to make sound management judgments. Besides, the results of the study will set a light to the future researcher on the point of being able to understand how organizational citizenship behavior effect emotional labor and of comprehending the correlation between the affection of work and organizational citizenship. 
Çolakoğlu, Ü., Yurcu, G., Atay, H., \& Yanık, A. (2015). Dimensional comparatives of organizational citizenship and emotional labor: A study on accommodation companies. International Journal of Human Sciences, 12(1), 933950. doi: $10.14687 /$ ijhs.v12i1.3086

In this study a significant positive correlation is found between organizational citizenship behavior and emotional labor. To explain briefly, employees exhibiting organizational citizenship behavior gain a stronger position against the negative effect of emotional labor waste. The positive relation occurs, to a large extent, in the surface acting phase of emotional labor. Thus, while employees are harmonizing their natural feelings arising in the phase of deep acting to the norms that the work necessitates in the phase of surface acting, organizational citizenship behavior shows a positive impact. At this point, it can be stated that organizational citizenship behavior also affects the function of emotion regulation positively. Herein, it can be advised to the managers in tourism enterprises which have a labor intensive characteristic to take organizational citizenship behavior as an element of solution in terms of reducing the negative effects of emotional labor over the employees. Managers should allocate a work environment in which the employees are able to exhibit organizational citizenship behavior.

According to the findings of the study, organizational citizenship behavior does not have a strong and significant effect in the suppression and deep acting phases of emotional labor. That is because the phases of deep acting and suppression, to a large extent, have an uncontrollable and unconscious characteristic. In the deep acting stage, the employee creates certain reflective emotions as a result of spontaneous dynamics of his internal world. These emotions can only be formed when they rise to the surface. That is why; organizational citizenship behavior doesn't have an influence in the matter of how or what the employee should feel; it has an influence over how the employee could manage and regulate the emotions he feels. At this point, organizations and managers may consider organizational citizenship behavior as a solution for the employee having difficulty in emotion regulation. They may also spend more time on providing appropriate environment for employees so as to exhibit voluntary behaviors in the organization in the dimensions of altruism, courtesy, conscience and chivalry.

Another matter taken into consideration in this study is whether job affection affects organizational behavior or not. According to the findings of the study, job affection has no effect on organizational citizenship behavior. In other words; there is no significant correlation between the employees' exhibiting organizational citizenship behavior and their job affection more or less. Even an employee having no job affection at all may exhibit organizational citizenship behavior or an employee having a lot of affection may not exhibit any organizational citizenship behavior. Therefore exhibiting organizational citizenship behavior is a more formal process for the employees. It provides the employee the opportunity of regulating the processes at his work and reaching his goals. Just like the case in emotional labor, it is a more superficial process not an 
Çolakoğlu, Ü., Yurcu, G., Atay, H., \& Yanık, A. (2015). Dimensional comparatives of organizational citizenship and emotional labor: A study on accommodation companies. International Journal of Human Sciences, 12(1), 933950. doi: $10.14687 /$ ijhs.v12i1.3086

interior one. In this study, the fact that job affection has no effect on OCB leads us to the result that OCB shows parallelism with emotional labor at the points of surface acting and emotional regulation.

\section{References}

Abraham, R. (1998). Emotional dissonance in organizations: antecedents, consequences and moderators, genetic. Social and General Psychology Monographs, 124 (2), 229-246.

Acquaah, G. (2004). Horticulture: principles and Practices. 3rd edition, Upper saddle River: New Jersey, Pearson Education Inc.

Ashforth, B. E., Humphrey, R. H. (1993). Emotional labor in service roles: the influence of identity. Academy of Management Review, 18 (1), 88-115.

Blakely, G. L., Andrews, M. C., Fuller, J. (2003). Are Chameleons Good Citizens? A Longitudinal Study of the Relationship between Self-Monitoring and Organizational Citizenship Behavior. Journal of Business \& Psychology, 18 (2), 131-144.

Callaghan, G., Thompson, P. (2002). "We Recruit Attitude": The Selection and Shaping of Routine Call Centre Labour. Journal of Management Studies, 39 (2), 233-254.

Chu, K. H., Murrmann, S. K. (2006). Development and validation of the hospitality emotional labor scale. Tourism Management, 27 (6), 1181-1191.

Constanti, P., Gibbs, P. (2005). Emotional Labour and Surplus Value: The Case of Holiday Reps. The Service Industries Journal, 25 (1), 103-116.

Cordes, C. L., Dougherty, T. W. (1993). A review and integration of research on job burnout. Academy of Management Review, 18 (4), 621-656.

Deluga, R. J. (1995). The relation between trust in the supervisor and subordinate organizational citizenship behavior. Military Psychology , 7 (1), 1-16.

Erickson, R. J., Wharton, A. S. (1997). Inauthenticity and depression: assessing the consequences of interactive service work. Work and Occupations, 24 (2), 188-213.

Feather, N. T. Rauter, K. A. (2004). Organizational Citizenship Behaviours in Relation to Job Status, Job Insecurity, Organizational Commitment and Identification, Job Satisfaction and Work Values. Journal of Occupational and Organizational Psychology, 77 (1), 81-94.

Finkelstein, M. A. Penner, L. A. (2004). Predicting Organizational Citizenship Behavior: Integrating the Functional and Role Identity Approaches. Social Behavior and Personality, 32 (4), 383-398.

Grandey, A. A. (2000). Emotion Regulation in the Workplace: A New Way to Conceptualize Emotional Labor. Journal of Occupational Health Psychology, 5 (1), 95-110.

Gray, B., Smith, P. (2009). Emotional labour and the clinical settings of nursing care: The perspectives of nurses in East London. Nurse Education in Practice, 9 (4), 253-261.

Greenberg, J., Baron, R.A. (2000) Behavior in organizations, (7th ed.) Upper Saddle River, NJ: Prentice-Hall.

Hall, E. J. (1993). Smiling, Deferring, and Flirting: Doing Gender by Giving "Good Service". Work and Occupations, 20 (4), 452-471.

Hochschild, A. R. (1983). The Managed Heart, University of California Press, Berkeley.

Huang, P. F., Dai, C. W. (2010). The Impacts of Emotional Contagion and Emotional Labor Perception on Employees' Service Performance. International Journal of Electronic Business Management, 8 (1), 68-79.

Hülsheger, U., Lang, J. W. B., Maier, G. W. (2010). Emotional labor, strain, and performance: Testing reciprocal relationships in a longitudinal panel study. Journal of Occupational Health Psychology, 15 (4), 505-521. 
Çolakoğlu, Ü., Yurcu, G., Atay, H., \& Yanık, A. (2015). Dimensional comparatives of organizational citizenship and emotional labor: A study on accommodation companies. International Journal of Human Sciences, 12(1), 933950. doi: $10.14687 /$ ijhs.v12i1.3086

Hwa, A. M. C., Thurasamy, R., Wafa, S. A. (2010). Exploring The Dimensionality of Emotional Labor: The Case of The Malaysian Hospitality Industry. International Journal of Business Research, 10 (1), 106.

James, N.(1989). Emotional labour: Skill and work in the social regulation of feelings. Sociologica Review, 37 (1), 15-42.

Katz, D. (1964). Motivational basis of organizational behavior. Behavioral Science, 9 (2), 131-146.

Koskina, A., Keithley, D. (2010). Emotion in a call centre SME: A case study of positive emotion management. European Management Journal, 28, (3), 208-219.

Lievens, F. Anseel, F. (2004). Confirmatory Factor Analysis and Invariance of an Organizational Citizenship Behaviour Measure Across Samples in a Dutch- Speaking Context. Journal of Occupational and Organizational Psychology, 77 (3), 299-306.

Levig, K. A., Dollard, M. F. (2003). Emotional dissonance, emotional exhaustion and job satisfaction in call centre workers. European Journal Of Work And Organizational Psychology, 12 (4), 366-392.

Man, F., Öz, C. S. (2007). Göründüğü Gibi Olamamak Ya Da Olduğu Gibi Görünememek: Çağr1 Merkezlerinde Duygusal Emek. Calısma ve Toplum, 1, 75-94.

McDonald, P. R. (1993). Individual-Organizational Value Congruence: Operationalization and Consequents. Unpublished Doctoral Dissertation. London, Ontario: The University of Western Ontario.

Moideenkutty U. (2000). Correlates and Outcomes of Organizational Citizenship Behavior Directed toward the Organization, the Supervisor, and CoNWorkers: A Social Exchange Perspective. Ph.D. Thesis, Temple University, Philadelphia.

Moorman, R. H. (1991). Relationship between organizational justice and organizational citizenship behaviors: Do fairness perceptions influence employee citizenship? Journal of Applied Psychology, 76 (6), 845-855.

Moorman, R. H., Blakely, G. L. (1995). Individualism-Collectivism as an individual difference predictor of organizational citizenship behavior. Journal of Organizational Behavior, 16 (2), 127142.

Moorman, R. H., Blakely, G. L., Niehoff, B. P. (1998). Does perceived organizational support mediate the relationship between procedural justice and organizational citizenship behavior? Academy of Management Journal, 41 (3), 351-357.

Moorman, R. H., Niehoff, B. P.,Organ, D. W. (1993). Treating employees fairly and organizational citizenship behavior: Sorting the effects of job satisfaction, organizational commitment, and procedural justice. Employee Responsibilities and Rights Journal, 6 (3), 209-225.

Motowidlo, S. J., Borman, W. C., Schmit, M. J. (1997). A theory of individual differences in task and contextual performance. Human Performance, 10 (2), 71-83.

Murphy, A. G. (1998). Hidden Transcripts of Flight Attendant Resistance. Management Communication Quarterly, 11 (4), 499-535.

Nakip, M. (2003), Paz̧arlama Araștırmalar Teknikler ve (SPSS Destekli) Uygulamalar, Seçkin Yayıncilık, Ankara.

Olson, T. M. (2004). What Lies Beneath Using Self Determination Theory to Understand The Motives Underlying Citizenship Behavior in Organizations, Ph.D. Thesis, Purdue University.

Organ, D. W. (1977). A reappraisal and reinterpretation of the satisfaction-causes-performance hypothesis. Academy of Management Review, 2 (1), 46-53.

Organ, D. W. (1988). Organizational citizenship behavior: the good soldier syndrome. Lexington Books/D. C. Heath and Com., Lexington, MA, England.

Organ, D. W., Konovsky, M. (1989). Cognitive versus affective determinants of organizational citizenship behavior. Journal of Applied Psychology, 74 (1), 157-164.

Podsakoff, P. M., MacKenzie, S. B. (1997). Impact of Organizational Citizenship Behavior on Organizational Performance: A Review and Suggestions for Future Research. Human Performance, 10 (2), 133-151. 
Çolakoğlu, Ü., Yurcu, G., Atay, H., \& Yanık, A. (2015). Dimensional comparatives of organizational citizenship and emotional labor: A study on accommodation companies. International Journal of Human Sciences, 12(1), 933950. doi: $10.14687 /$ ijhs.v12i1.3086

Podsakoff, P.M., MacKenzie, S.B., Lee, J., Podsakoff, N.P. (2003). Common method biases in behavioral research: A critical review of the literature and recommended remedies. Journal of Applied Psychology, 88 (5), 879-903.

Price, H. (2001). Emotional labour in the classroom: a psychoanalytic perspective. Journal Of Social Work Practice, 15 (2), 161-180.

Schnake, M. E., Dumler, M. P. (2003). Levels of Measurement and Analysis Issues in Organizational Citizenship Behaviour Research. Journal of Occupational and Organizational Psychology, 76 (3), 283-301.

Shuler, S., Sypher, B. D. (2000). Seeking Emotional Labour: Whenmanaging Heart Enhances the Work Experience. Management Communication Quarterly, 14 (1), 50-89.

Smith, C.; Organ D. W., J. Near (1983) Organizational Citizenship Behavior: Its Nature and Antecedents, Journal of Applied Psychology, 68, (4), 653-663.

Somech, A., Drach-Zahavy, A. (2000). Understanding extrarole behavior in schools: The relationships between job satisfaction, sense of efficacy, and teachers' extra-role behavior. Teaching and Teacher Education, 16 (5-6), 649-659.

Sutton, R. I., Rafaeli, A. (1988). Untangling the relationship between displayed emotions and organizational sales: the case of convenience stores. Academy of Management Journal, 31 (3), 461-487.

Tracy, S. J. (2000). Becoming a Character for Commerce: Emotional Labour, Self-subordination, and Discursive Construction of Identity in a Total Institution. Management Communication Quarterly, 14 (1), 90-128.

Truc, H., Marie, A., Mary, T. (2008). Emotional labour underlying caring: an evolutionary concept analysis. Journal of Advanced Nursing, 64 (2), 195-208.

Turnipseed, D., Murkison, G. (2000). Good Soldiers and Their Syndrome: Organizational Citizenship Behavior and The Work Environment. North American Journal of Psychology, 2 (2), 281-302.

Vey, M. A., Campbell, J. P. (2004). In-Role or Extra-Rol Organizational Citizenship Behavior: Which Are We Measuring? Human Performance, 17 (1), 119-135.

Wagner, S. L., Rush, M. C. (2000). Altruistic organizational citizenship behavior: Context, disposition, and age. Journal of Social Psychology, 140 (3), 379-391.

Williams, L. J., Anderson, S. E. (1991). Job satisfaction and organizational commitment as predictors of organizational citizenship and in-role behaviors. Journal of Management, 17 (3), 601-617.

Wilton, R. D. (2008). Workers with disabilities and the challenges of emotional labour. Disabilityersociety, 23 (4), 361-373.

Wong, J., Wang, C. (2009). Emotional Labor of the Tour Leaders: An Exploratory Study. Tourism Management, 30 (2), 249-259.

Zapf, D. (2002). Emotion work and psychological well-being: a review of the literature and some conceptual considerations. Human Resource Management Review, 12 (2), 237-268. 